\title{
Actinomyces marimammalium sp. nov., from marine mammals
}

\author{
Lesley Hoyles, ${ }^{1}$ Cristina Pascual, ${ }^{1}$ Enevold Falsen, ${ }^{2}$ Geoffrey Foster, ${ }^{3}$ \\ John M. Grainger ${ }^{4}$ and Matthew D. Collins ${ }^{1}$
}

Author for correspondence: Matthew D. Collins. Tel: +44 118 9357226. Fax: +44 1189357222. e-mail: m.d.collins@reading.ac.uk

\footnotetext{
1 Department of Food Science and Technology, University of Reading, Whiteknights, PO Box 226, Reading RG6 6AP, UK

2 Culture Collection, Department of Clinical Bacteriology, University of Göteborg, Sweden

3 SAC Veterinary Science Division, Inverness, UK

4 Department of Animal and Microbial Sciences, University of Reading, UK
}

\begin{abstract}
Three strains of a previously undescribed Actinomyces-like bacterium were isolated from samples taken from two dead seals and a porpoise. Biochemical testing and PAGE analysis of whole-cell proteins indicated the strains were phenotypically similar to each other but different from previously described Actinomyces and Arcanobacterium species. Comparative 16S rRNA gene sequencing studies showed the organisms from marine animals were genetically closely related and represent a hitherto unknown subline within the genus Actinomyces (sequence divergence values $>6 \%$ with recognized species). Based on phylogenetic and phenotypic evidence it is proposed that the unknown bacterium from the seals and a porpoise should be classified as Actinomyces marimammalium sp. nov. The type strain is CCUG 41710'.
\end{abstract}

Keywords: taxonomy, phylogeny, Actinomyces marimammalium, 16S rRNA

\section{INTRODUCTION}

In recent years, the Gram-positive asporogenous rodshaped organisms of the genus Actinomyces and related taxa have attracted the attention of clinical microbiologists, mainly because of a growing awareness of their presence in clinical specimens and also because of increased taxonomic interest (Funke et al., 1997a). Knowledge of the taxonomic inter-relationships of species of the genus Actinomyces has improved dramatically in recent years particularly with the use of 16S rRNA gene sequencing (Pascual et al., 1997a; Lawson et al., 1997). Indeed, the application of molecular sequence data in conjunction with improved phenotypic methods of analysis has not only resulted in better species identification but also greatly facilitated the recognition of new taxa, particularly from human clinical sources [e.g. Actinomyces europaeus (Funke et al., 1997b); Actinomyces graevenitzii (Pascual et al., 1997b); Actinomyces neuii subspp. anitratus and neuii (Funke et al., 1994); Actinomyces radingae (Wüst et al., 1995); Actinomyces turicensis (Wüst et al., 1995); Actinomyces urogenitalis (Nikolaitchouk et al., 2000); Actinobaculum schaalii (Lawson et al., 1997);

Abbreviation: CCUG, Culture Collection of the University of Göteborg. The GenBank accession number for the 16S rRNA gene sequence of strain CCUG $41710^{\top}$ is AJ 276405 .
Arcanobacterium bernardiae (Funke et al., 1995)]. The presence of Actinomyces-like organisms in wild and domestic animals has received much less attention, although there are indications that the implementation of improved diagnostic methods will result in a better understanding of their host distribution and possible association with animal disease (Pascual et al., 1997a, 1999). In this article, we report the polyphasic characterization (using phenotypic and molecular techniques in concert) of three unusual Actinomyces-like bacteria isolated from two dead seals and a porpoise. Based on the presented findings, yet another new species of the genus Actinomyces, Actinomyces marimammalium sp. nov., is described.

\section{METHODS}

Cultures and cultivation. Strain M1749/98/1 ${ }^{\mathrm{T}}$ (CCUG $41710^{\mathrm{T}}$ ) was isolated in mixed culture with Escherichia coli, Streptococcus spp. and Actinobacillus spp. from multiple organs (lung, spleen, liver, kidney, mesenteric lymph node) of a dead male hooded seal (Cystophara cristata) which had suffered from pneumonia, whereas strain M514/99/2 (CCUG 43292) was isolated from the small intestine of a dead grey seal (Halichoerus grypus) which had been shot. Strain M1349/94/2 (CCUG 42833) originated from the lung of a dead harbour porpoise (Phocoena phocoena). The unidentified Actinomyces-like isolates were cultured on Columbia agar (Difco) supplemented with $5 \%$ sheep blood at $37^{\circ} \mathrm{C}$, in air plus $5 \% \mathrm{CO}_{2}$. The strains were biochemically 


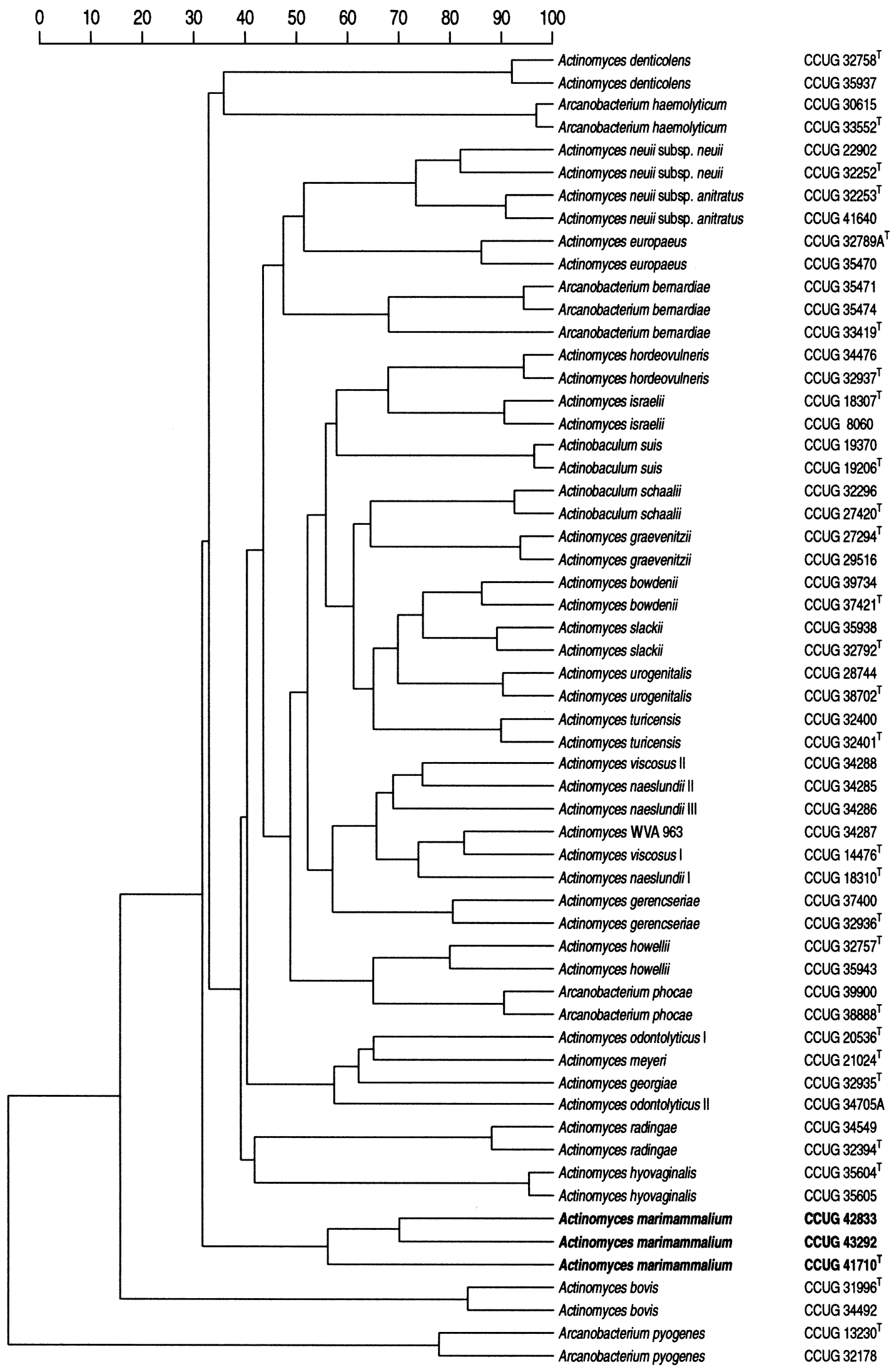

Fig. 1. Similarity dendrogram based on whole-cell protein patterns of Actinomyces marimammalium sp. nov. and related species. Levels of correlation are expressed as percentages of similarity for convenience. 
characterized by using the API rapid ID32Strep and API coryne systems according to the manufacturer's instructions (API bioMérieux).

Protein profiling. PAGE analysis of whole-cell proteins was performed as described by Pot et al. (1994). For densitometric analysis, normalization and interpretation of protein patterns the GCW 3.0 software package (Applied Maths) was used. The similarity between all pairs of traces was expressed by the Pearson product moment correlation coefficient converted for convenience to a percentage similarity.

16SrRNA gene sequencing and phylogenetic analysis. The $16 \mathrm{~S}$ rRNA genes of the isolates were amplified by PCR and directly sequenced using a Taq Dye-Deoxy Terminator Cycle Sequencing kit (Applied Biosystems) and an automatic DNA sequencer (model 373A, Applied Biosystems). The closest known relatives of the new isolates were determined by performing database searches. These sequences and those of other known related strains were retrieved from the GenBank or Ribosomal Database Project libraries and aligned with the newly determined sequences using the program PILEUP (Devereux et al., 1984). The resulting multiple sequence alignment was corrected manually and a distance matrix was calculated using the programs PRETTY and DNADIST (using the Kimura 2-correction parameter) (Felsenstein, 1989). A phylogenetic tree was constructed according to the neighbour-joining method with the program NEIGHBOR (Felsenstein, 1989). The stability of the groupings was estimated by bootstrap analysis (500 replications) using the programs SEQBOOT, DNADIST, NEIGHBOR and CONSENSE (Felsenstein, 1989).

\section{RESULTS AND DISCUSSION}

The three isolates consisted of Gram-positive straight to slightly curved rods, some of which displayed branching. Cells were non-acid-fast and non-sporeforming. The strains grew under aerobic and anaerobic conditions and were catalase-negative. The isolates phenotypically resembled each other, producing acid from glucose, maltose, lactose and $N$-acetyl- $\beta$-glucosamine. None of the isolates produced acid from L-arabinose, D-arabitol, cyclodextrin, mannitol, melibiose, melizitose, methyl- $\beta$-D-glucopyranoside, pullulan, raffinose, ribose, sorbitol, sucrose, tagatose or D-xylose. All strains were positive for alanine phenylalanine proline arylamidase, $\beta$-galactosidase, $\beta$-galacturonidase and glycyl tryptophan arylamidase, but were negative for arginine dihydrolase, pyrazinamidase, $\alpha$-galactosidase, $\alpha$-glucosidase, $\beta$-glucosidase, $\beta$-glucuronidase, $\beta$-mannosidase, pyroglutamic acid arylamidase, pyrolydonyl arylamidase and urease. Variable reactions were observed for alkaline phosphatase. The three isolates failed to produce alkaline phosphatase using the API rapid ID32Strep system, but strains CCUG $41710^{\mathrm{T}}$ and CCUG 43292 were weakly positive using the API coryne system. None of the isolates hydrolysed aesculin, gelatin or hippurate and they were Voges-Proskauer-negative and failed to reduce nitrate. The rapid ID32Strep codes for CCUG
$41710^{\mathrm{T}}, 42833$ and 43292 were 40016601000, 40002600000 and 40016601000 , respectively, and those for the coryne system were 0520162, 0420160 and 0520160 , respectively. The cellular morphology and general biochemical reactions of the isolates were consistent with their preliminary assignment to the genus Actinomyces. An examination of the long-chain cellular fatty acids of a representative strain (CCUG $41710^{\mathrm{T}}$ ) revealed acids of the straight-chain saturated and monounsaturated types with hexadecanoic (C16:0, 39.8\%), octadecanoic $(\mathrm{C} 18: 0,22.8 \%)$ and cis-delta 9-octadecenoic (C18:1cis 9, 31.5\%) predominating. This cellular fatty acid composition is consistent with members of the genus Actinomyces.

The results of a comparative analysis of whole-cell protein profiles of the unknown strains and other Actinomyces species by SDS-PAGE is shown in Fig. 1. The three isolates were recovered in a single group which was well separated from all other reference species examined. The phylogenetic position of the unknown organisms was determined by comparative $16 \mathrm{~S}$ rRNA gene sequencing. The almost complete gene sequence $(>1500 \mathrm{nt})$ of the three isolates was determined and pairwise analysis showed these to be highly related $(>99 \cdot 5 \%)$. Sequence database searches confirmed the unknown bacterium was most closely related to species of the genus Actinomyces. Highest sequence similarity (approx. 93\%) was shown with Actinomyces hordeovulneris, other species showing lower levels of relatedness (Table 1). Treeing analysis further demonstrated the distinctiveness of the unknown Actinomyces species (as exemplified by strain CCUG $41710^{\mathrm{T}}$ ) (Fig. 2). The bacterium formed a relatively long subline clustering with Actinomyces hordeovulneris, although bootstrap resampling demonstrated the association between these taxa was not statistically significant (bootstrap value $68 \%$ for 500 tree replications) (Fig. 2).

It is apparent from both phenotypic and phylogenetic evidence that the two unidentified isolates recovered from seals and the isolate from a porpoise represent a hitherto unknown Actinomyces species. Both $16 \mathrm{~S}$ rRNA sequence divergence values and treeing analysis show the bacterium represents a distinct subline within the genus Actinomyces. The nearest phylogenetic relative of the unknown bacterium corresponds to Actinomyces hordeovulneris, although a sequence divergence of $7 \%$ shows this affinity is not particularly close. The unidentified bacterium can be biochemically readily distinguished from Actinomyces hordeovulneris in not fermenting pullulan and D-xylose, and not producing $\alpha$-galactosidase. By contrast Actinomyces hordeovulneris ferments these carbohydrates and is $\alpha$ galactosidase-positive. The unknown bacterium also differs markedly from Actinomyces hordeovulneris in PAGE analysis of whole-cell proteins. Thus based on the results of the reported polyphasic taxonomic study, we consider the unknown bacterium merits classification as a new species of the genus Actinomyces, for 
Table 1. $16 \mathrm{~S}$ rRNA gene sequence similarity values for Actinomyces marimammalium sp. nov. against all currently recognized Actinomyces species and phylogenetically related species

\begin{tabular}{|c|c|c|}
\hline Species & Accession no. & 16S rRNA sequence similarity $(\%)$ \\
\hline Actinobaculum schaalii & Y12329 & $90 \cdot 5$ \\
\hline Actinobaculum suis & S83623 & $89 \cdot 1$ \\
\hline Actinomyces bovis & X81061 & $91 \cdot 5$ \\
\hline Actinomyces bowdenii & AJ234039 & $90 \cdot 4$ \\
\hline Actinomyces canis & AJ243891 & $92 \cdot 7$ \\
\hline Actinomyces denticolens & X80412 & $90 \cdot 2$ \\
\hline Actinomyces europaeus & Y08828 & $91 \cdot 7$ \\
\hline Actinomyces georgiae & X80413 & $90 \cdot 8$ \\
\hline Actinomyces gerencseriae & X80414 & $88 \cdot 3$ \\
\hline Actinomyces graevenitzii & Y09589 & $90 \cdot 2$ \\
\hline Actinomyces hordeovulneris & X82448 & $92 \cdot 9$ \\
\hline Actinomyces howellii & X80411 & $90 \cdot 6$ \\
\hline Actinomyces hyovaginalis & X69616 & $91 \cdot 7$ \\
\hline Actinomyces israelii & X82450 & $88 \cdot 7$ \\
\hline Actinomyces meyeri & X82451 & $91 \cdot 7$ \\
\hline Actinomyces naeslundii & X81062 & $91 \cdot 5$ \\
\hline Actinomyces odontolyticus & AJ 234040 & $92 \cdot 0$ \\
\hline Actinomyces radingae & X78719 & $88 \cdot 4$ \\
\hline Actinomyces slackii (clone 1) & AJ234066 & $90 \cdot 3$ \\
\hline Actinomyces turicensis & X78720 & $90 \cdot 3$ \\
\hline Actinomyces urogenitalis & AJ243791 & $91 \cdot 7$ \\
\hline Actinomyces viscosus & X82453 & $91 \cdot 1$ \\
\hline Arcanobacterium bernardiae & X79224 & $90 \cdot 4$ \\
\hline Arcanobacterium haemolyticum & AJ234059 & $91 \cdot 3$ \\
\hline Arcanobacterium phocae & X97049 & $91 \cdot 5$ \\
\hline Arcanobacterium pyogenes & X79225 & $91 \cdot 0$ \\
\hline Mobiluncus curtisii & X53186 & $91 \cdot 0$ \\
\hline
\end{tabular}

which the name Actinomyces marimammalium sp. nov. is proposed. Tests which are useful in distinguishing Actinomyces marimammalium from some other animal Actinomyces species are shown in Table 2.

\section{Description of Actinomyces marimammalium sp. nov.}

Actinomyces marimammalium (ma.ri.mam.ma'li.um. L. neut. n. mare the sea; M.L. neut. gen. pl. n. mammalium of mammals; M.L. marimammalium of marine mammals).

Cells are straight to slightly curved rods, some of which exhibit branching. Cells stain Gram-positive, are non-acid-fast and non-motile. Colonies are grey, entire, circular, convex and pin-point to $0.5 \mathrm{~mm}$ in diameter at $48 \mathrm{~h}$. Non-haemolytic. Facultatively anaerobic and catalase-negative. Acid is produced from D-glucose, maltose, lactose and $N$-acetyl- $\beta$-glucosamine. Acid is not produced from L-arabinose, Darabitol, cyclodextrin, mannitol, melibiose, melezitose, methyl- $\beta$-D-glucopyranoside, pullulan, raffinose, Dribose, sorbitol, sucrose, trehalose, tagatose or $\mathrm{D}$ xylose. Acid may or may not be produced from glycogen. Aesculin, gelatin and hippurate are not hydrolysed. Alanine phenylalanine proline arylamidase, $\beta$-galactosidase, $\beta$-galacturonidase, leucine arylamidase and glycyl tryptophan arylamidase are produced. $\alpha$-Galactosidase, $\alpha$-glucosidase, $\beta$-glucosidase, $\beta$-glucuronidase, arginine dihydrolase, pyroglutamic acid arylamidase, pyrazinamidase, urease, $\beta$-mannosidase and pyrolydonyl arylamidase are not produced. Activity for alkaline phosphatase may or may not be detected. Acetoin is not produced. Nitrate is not reduced to nitrite. The end products of glucose metabolism are acetic, lactic and succinic acids. The $\mathrm{G}+\mathrm{C}$ content of DNA is $66 \mathrm{~mol} \%$. Isolated from sea mammals (hooded seal, grey seal and harbour porpoise). Habitat is not known. The type strain is CCUG $41710^{\mathrm{T}}$ (CIP $106509^{\mathrm{T}}$ ). The type strain exhibits the characteristics of the species and produces acid from glycogen.

\section{ACKNOWLEDGEMENTS}

We are grateful to Professor Hans Trüper for help in coining the species epithet and to Lena Dahl for performing PAGE analysis. The ongoing study of Scottish Strandings is 


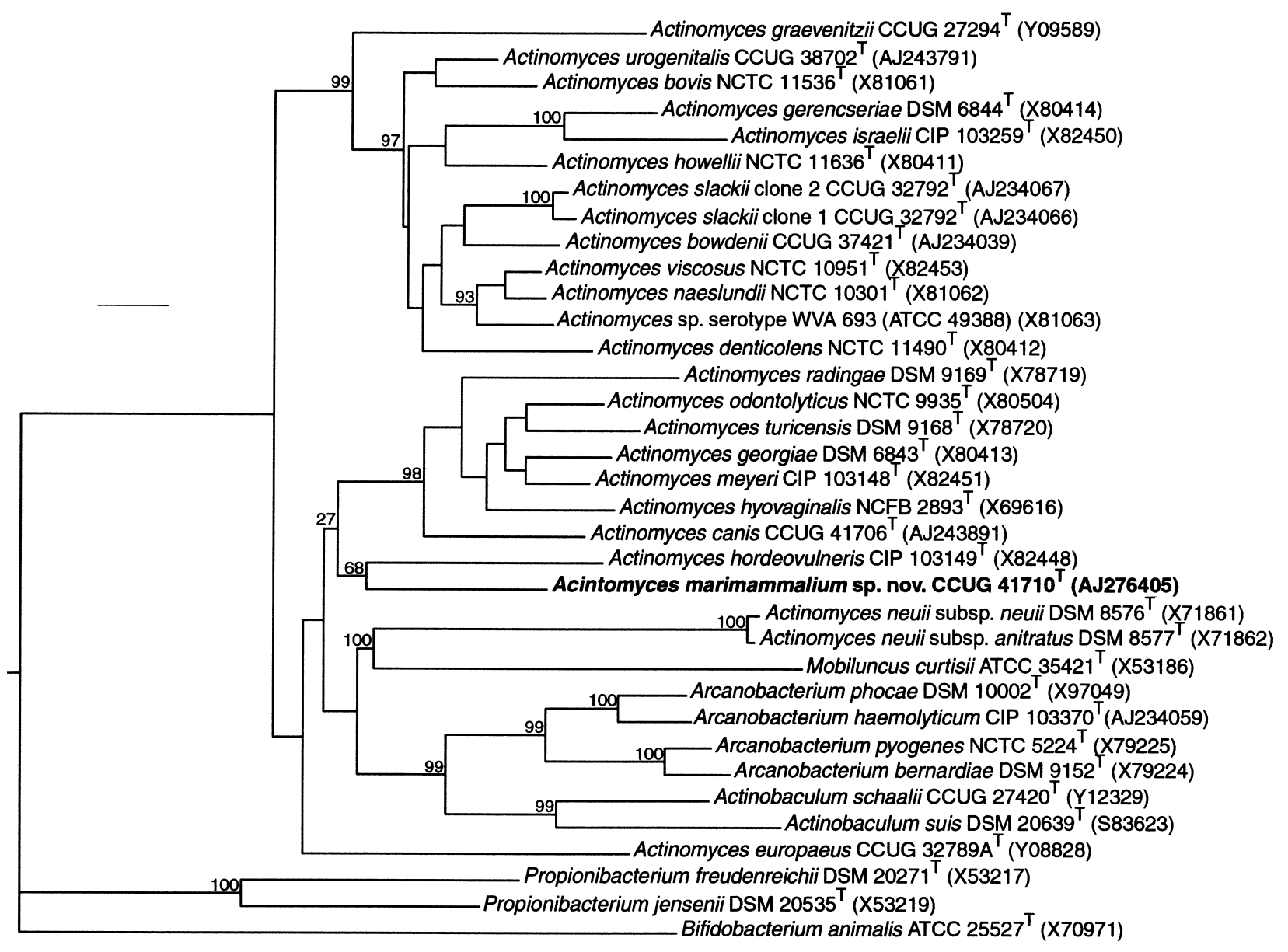

Fig. 2. Unrooted tree showing the phylogenetic relationships of Actinomyces marimammalium sp. nov. and some other high $\mathrm{G}+\mathrm{C}$ content Gram-positive bacteria. The tree, constructed using the neighbour-joining method, was based on a comparison of approximately $1327 \mathrm{nt}$. Bootstrap values, expressed as a percentage of 500 replications, are given at branching points. Scale bar, $1 \%$ sequence divergence.

Table 2. Tests useful in distinguishing Actinomyces marimammalium from some other animal Actinomyces species + , Positive; - , negative; $v$, variable $;+^{(-)}$, a few strains negative; $-^{(+)}$, a few strains positive.

\begin{tabular}{|c|c|c|c|c|c|c|c|c|c|c|c|c|c|c|c|}
\hline \multirow[t]{2}{*}{ Species } & \multicolumn{6}{|c|}{ Acid from*: } & \multicolumn{7}{|c|}{ Production of $\uparrow:$} & \multirow{2}{*}{$\begin{array}{c}\text { Reduction of } \\
\mathrm{NO}_{3}\end{array}$} & \multirow{2}{*}{$\begin{array}{l}\text { Hydrolysis of } \\
\text { aesculin }\end{array}$} \\
\hline & L-Ara & Mlz & D-Rib & Suc & Tre & D-Xyl & $\alpha$-Gal & $\alpha$-Glu & $\beta$-Glu & Pyr & GTA & NAG & APPA & & \\
\hline A. marimammalium sp. nov. & - & - & - & - & - & - & - & - & - & - & + & + & + & - & - \\
\hline A. bovis & - & - & - & $+^{(-)}$ & - & - & - & - & $\mathrm{v}$ & - & $\mathrm{v}$ & $-{ }^{(+)}$ & - & - & $+^{(-)}$ \\
\hline A. bowdenii & - & + & $\mathrm{v}$ & + & + & - & + & $\mathrm{v}$ & + & $\mathrm{v}$ & - & - & + & + & + \\
\hline A. canis & + & - & + & $\mathrm{v}$ & - & + & + & + & - & + & $\mathrm{v}$ & + & + & - & - \\
\hline A. denticolens & - & $\mathrm{v}$ & $\mathrm{v}$ & + & $\mathrm{v}$ & $\mathrm{v}$ & + & + & + & $\mathrm{v}$ & - & - & $\mathrm{v}$ & + & + \\
\hline A. hordeovulneris & - & - & - & $\mathrm{v}$ & $\mathrm{v}$ & + & + & $\mathrm{v}$ & + & $\mathrm{v}$ & + & + & + & - & + \\
\hline A. howellii & - & $\mathrm{v}$ & - & + & $\mathrm{v}$ & + & + & + & + & + & - & $\mathrm{v}$ & + & - & + \\
\hline A. hyovaginalis & $t^{(-)}$ & - & + & + & - & + & + & + & + & $\mathrm{v}$ & - & $\mathrm{v}$ & + & $\mathrm{v}$ & + \\
\hline A. slackii & - & - & - & + & + & + & + & + & + & + & - & - & - & + & + \\
\hline
\end{tabular}

* Fermentation of: L-Ara, L-arabinose; Mlz, melezitose; D-Rib, D-ribose; Suc, sucrose; Tre, trehalose; D-Xyl, D-xylose.

$\dagger \alpha$-Gal, $\alpha$-galactosidase; $\alpha$-Glu, $\alpha$-glucosidase; $\beta$-Glu, $\beta$-glucosidase; Pyr, pyrazinamidase; GTA, glycyl tryptophan arylamidase; NAG, $N$-acetyl- $\beta$-glucosaminidase; APPA, alanyl-phenylalanine proline arylamidase. 
conducted under contract to the UK Department of the Environment, Transport and Regions as part of its coordinated programme of research on the North Sea.

\section{REFERENCES}

Devereux, J., Haeberli, P. \& Smithies, O. (1984). A comprehensive set of sequence analysis programs for the VAX. Nucleic Acids Res 12, 387-395.

Felsenstein, J. (1989). PHYLIP - phylogeny inference package (version 3.2). Cladistics 5, 164-166.

Funke, G., Stubbs, S., von Graevenitz, A. \& Collins, M. D. (1994). Assignment of human-derived CDC group 1 coryneform bacteria and CDC group 1-like coryneform bacteria to the genus Actinomyces as Actinomyces neuii subsp. neuii sp. nov., subsp. nov., and Actinomyces neuii subsp. anitratus subsp. nov. Int J Syst Bacteriol 44, 167-171.

Funke, G., Pascual Ramos, C., Fernandez-Garayzabal, J., Weiss, N. \& Collins, M. D. (1995). Description of human-derived Centers for Disease Control coryneform group 2 bacteria as Actinomyces bernardiae sp. nov. Int J Syst Bacteriol 45, 57-60.

Funke, G., von Graevenitz, A., Clarridge, J. E. \& Bernard, K. A. (1997a). Clinical microbiology of coryneform bacteria. Clin Microbiol Rev 10, 125-159.

Funke, G., Alvarez, N., Pascual, C., Falsen, E., Akervall, E., Sabbe, L., Schouls, L., Weiss, N. \& Collins, M. D. (1997b). Actinomyces europaeus sp. nov., isolated from human clinical specimens. Int J Syst Bacteriol 47, 687-692.

Lawson, P. A., Falsen, E., Akervall, E., Vandamme, P. \& Collins, M. D. (1997). Characterization of some Actinomyces-like isolates from human clinical specimens: reclassification of Actinomyces suis (Soltys and Spratling) as Actinobaculum suis comb. nov. and description of Actinobaculum schaalii sp. nov. Int J Syst Bacteriol 47, 899-903.

Nikolaitchouk, N., Hoyles, L., Falsen, E., Grainger, J. M. \& Collins, M. D. (2000). Characterization of Actinomyces isolates from samples from the human urogenital tract: description of Actinomyces urogenitalis sp. nov. Int J Syst Evol Microbiol 50, 1649-1654.

Pascual, C., Foster, G. \& Collins, M. D. (1997a). Phylogenetic analysis of the genus Actinomyces based on 16S rRNA gene sequences: description of Arcanobacterium phocae sp. nov., Arcanobacterium bernardiae comb. nov., and Arcanobacterium pyogenes comb. nov. Int J Syst Bacteriol 47, 46-53.

Pascual, C., Falsen, E., Akervall, E., Sjoden, B. \& Collins, M. D. (1997b). Actinomyces graevenitzii sp. nov., isolated from human clinical specimens. Int $J$ Syst Bacteriol 47, 885-888.

Pascual, C., Foster, G., Falsen, E., Bergstrom, K., Greko, C. \& Collins, M. D. (1999). Actinomyces bowdenii sp. nov., isolated from canine and feline sources. Int J Syst Bacteriol 49, 1873-1877.

Pot, B., Vandamme, P. \& Kersters, K. (1994). Analysis of electrophoretic whole-organism protein fingerprints, In Modern Microbial Methods. Chemical Methods in Prokaryotic Systematics, pp. 493-521. Edited by M. Goodfellow \& A. G. O'Donnell. Chichester: Wiley.

Wüst, J., Stubbs, S., Weiss, N., Funke, G. \& Collins, M. D. (1995). Assignment of Actinomyces pyogenes-like (CDC coryneform group E) bacteria to the genus Actinomyces as Actinomyces radingae sp. nov. and Actinomyces turicensis sp. nov. Lett Appl Microbiol 20, 76-81. 